\title{
ЕПОХА ПОСТКОРОНАВІРУСНИХ ЕКОНОМІЧНИХ ТРАНСФОРМАЦІЙ ТА ЇХ ВПЛИВ НА ЦИФРОВІ БІЗНЕС-МОДЕЛІ
}

Анотація. У сучасному суспільстві за часів світової пандемії особливе місце займає процес переходу бізнесу в онлайн середовище. Зокрема, майже половина підприемств на початку карантину в березні 2020 року була закрита або була на межі закриття, що призвело до того, що бізнес-середовище було вимушене швидко адаптувалося до сучасної ситуащії. Виникла необхідність активно залучати програми дистанційної роботи. У статті було проаналізовано вплив карантинних обмежень на бізнес-сореру, наведено статистичні дані впливу диджіталізації підприемств у умовах коронавірусної епохи. Також, було проведено дослідження щодо введення нових шляхів покращення економічних наслідків в сучасних умовах, зокрема, виділено роль керівника підприемства, такі зміни як пришвидшення функціонування цифрової бізнес-моделі підприємства. Було узагальнено поняття безпосередньо самої бізнес-моделі як складової мехіанізму роботи підприемства. Загалом, цифровізація процесів актуальна не лише на рівні окремих компаній: цілі галузі обирають цей шлях розвитку як единий спосіб реагування на швидко мінливі умови навколишнього середовища. Завдяки цьому цифрова трансформація промисловості, роздрібної торгівлі, державного сектору та інших сфер вже змінюе життя кожної людини та кожного бізнесу. Загалом впровадження цифрових технологій розмиває географічні та фрізичні кордони та відкриває нові економічні перспективи, сощіальний та культурний розвиток країн, а також зростання регіональної та глобальної конкурентоспроможності. Пришвидшення диджіталізації на практиці показуе високі показники продуктивності, а експерти говорять що карантин допоміг зробити справу наступних років. Без перебільшень локдаун за часів коронавірусу здійснив безпрецедентний вплив на увесь світ, але серйозні проблеми все ж таки залишаються. Компанії повинні запроваджувати цифрові бізнес-моделі сьогодні, якшо вони хочуть продовжувати існувати на економічному ринку в майбутньому. Тимчасові вдосконалення, які задовольняють клієнтів сьогодні, можуть стати постійними компонентами, що покращують роботу бізнес-компаній на протязі найближчих років.

Ключові слова: економічні трансформації, цифрові бізнес-моделі, онлайн-платформи, диджіталізація.

Pokhylko Svitlana, Hrytsenko Larysa, Martymianov Artem Sumy State University

\section{THE ERA OF POSTCORONAVIRUS ECONOMIC TRANSFORMATIONS AND ITS IMPACT ON DIGITAL BUSINESS MODELS}

Summary. The transition of businesses to the online environment has a special place in modern society at the time of global pandemic, In particular, nearly half of the businesses were closed or were on the verge of closing at the beginning of the quarantine in March 2020, forcing the business environment to adapt quickly to the current situation. There was a need to actively pursue telecommuting and remote work programs. The article analyzed the strong effect of quarantine restrictions on the business environment, providing statistical data on the impact of the digitalization of businesses in the coronavirus era. The authors also conducted research on the introduction of new ways to improve the economic consequences in today's environment, particularly highlighting the role of an enterprise manager and such changes as the acceleration of digital business model of an enterprise. The article summarized the concept of a business model as a component of the mechanism of the company. In general, the digitalization of business processes is not only relevant to the level of individual companies, some huge industries are choosing this development path as the only way to respond to rapidly changing environmental conditions. Because of this, the digital transformation of industry, retail, the public sector and other areas is already changing the lives of every person and every business. Overall, the introduction of digital technologies is blurring geographic and physical boundaries and opening up new economic prospects, social and cultural development of countries, as well as the growth of regional and global competitiveness. Accelerating digitalization in practice shows high productivity rates, and some experts say that quarantine has helped make the case for the next years. The Coronavirus lockdown has had an unprecedented influence on the economy around the world, but a considerable amount of serious challenges still remains to be done. Companies must adopt digital business models today if they want to continue to exist in the economic marketplace in the future. Temporary improvements that satisfy customers today can become permanent components that improve business operations for many years in advance.

Keywords: economic transformations, digital business models, online platforms, digitalization.

Постановка проблеми. Сучасне бізнес-середовище постійно змінюеться, значною мірою завдяки переходу на цифрові технології та глобалізації. Ось чому сьогоднішнім бізнеслідерам важливо використовувати ключові бізнес-знання, щоб зрозуміти поточний стан справ і приймати ефрективні рішення. Тому вищому керівництву необхідно впроваджувати цифрові бізнес-моделі, краще розуміти бізнес і мати єдину версію довіреної інформації. Початок карантину поставив перед бізнес-сектором купу запитань. Карантинні обмеження призупинили дію 
сфрери послуг, що понесло величезні збитки для підприемців. Виникла необхідність швидкого підлаштовування під умови сьогодення. Таким чином, розпочався активний процес переходу механізмів ведення бізнесу на онлайн-платформи. У свою чергу, це прискорило процес цифрровізації усіх сфрер суспільства.

Аналіз останніх досліджень і публікацій. Дане питання активно досліджували вітчизняні науковці, які надають свою оцінку процесам, що на сьогодні відбуваються у сырері бізнесу. Серед них варто виділити: Шевченко Л.С., Лісову P.М., Боденчук Л.Б., Ліганенко I.В., Цвіркун Я., Дерев'янко А., Андрощук Г., Ларіонова Г., Пищуліна О. та інші.

Виділення не вирішених раніше частин загальної проблеми. Посилення карантинних заходів, неможливість прогнозування майбутніх наслідків вимагае постійного дослідження даної проблеми. Регулювання сфери бізнесу має вагоме значення для економіки країни, для громадян, які втрачають сьогодні робочі місця, та для підприемців, для яких головна мета на сьогодні - врятувати свою справу за допомогою вдало підібраної ефрективної цифрової бізнес-моделі для їх підприємства. Дане питання потребує подальшого дослідження, незважаючи на ряд робіт, опублікованих за даною проблемою.

Мета статті. Головною метою даної роботи $€$ дослідження впливу COVID-19 на розвиток економіки та аналіз ситуації, яка склалась довкола сорери диджіталізації. дослідження щодо введення нових шляхів покращення економічних наслідків в умовах поскороновірусного середовища.

Виклад основного матеріалу. Темпи розвитку, пов'язані з динамічною зміною правил бізнесу в цифрову епоху, вказують на необхідність для компаній володіти такими якостями, такими як динамізм i передбачливість, а також розробляти власну стратегію цифрової трансформації. Циорова трансформація - це використання сучасних (проривних) технологій для підвищення продуктивності та цінності бізнесу в сучасному світі. Основними результатами такої трансформащії можуть бути: зниження витрат, покращення якості послуг і продукцї та підвищення продуктивності праці.

Дослідження КРMG показують, що у 61\% компаній цифрові технології допомогли посилити конкуренщію в їхньому бізнесі з боку нових гравців. Сьогодні 44\% компаній у світі мають цифрову стратегію розвитку.

Циррова трансрормація бізнес-моделі може відбуватися на рівні окремих її елементів або всієї бізнес-моделі. Ступінь ДТ включає послідовні (граничні) або радикальні (фундаментальні) зміни БМ. Орієнтиром рівня новизни є насамперед клієнт, але DT також може впливати на власну компанію, партнерів, галузь та конкурентів [1].

Бізнес-модель має багато визначень, як-от: концептуальний опис підприемницької діяльності; набір процесів, необхідних для нормального фрункціонування компанії спосіб отримання прибутку; режим, за яким працюе підприемство та інші. Вибрана компанією бізнес-модель повинна узгоджувати її цілі та бізнес-процеси з реаліями зовнішнього середовища, а отже - реалізовувати стратегію компанії [2].
Сьогодні людство перебуває на проміжній стадії інституційної траєкторії переходу від Ното economicus (економічна людина) до netman (людина мережі) - Homo smartphonicus. Людина без смартфона 3 QR-кодами сьогодні де-фракто вже не може правильно виконувати свої соціальноекономічні фрункції, зокрема як клієнт банку. А це криє в собі великий ризик дегуманізації банківських систем і цифррової сегрегації суспільства загалом [3].

У рамках цифррової трансдрормації бізнес-моделі для створення нових програм або послуг використовуються програмні засоби та технології (наприклад, великі дані). Ці фрактори вимагають навичок, які дозволяють збирати та обмінюватися даними, а також вміти аналізувати, обчислювати й оцінювати варіанти. Розраховані параметри використовуються для запуску нових процесів у бізнес-моделі. Трансформація бізнес-моделей базуеться на підході 3 послідовністю завдань і взаємопов'язаних рішень у логічному та тимчасовому контекстах. Він впливає на чотири цільові виміри: час, фрінанси, простір і якість [4].

В умовах цифррової трансформації бізнесмоделі загалом зазнає змін. Процес створення цінності проходить у мережевому просторі взаємодій різних партнерів та перетинання (додавання) моделей індивідуальних справ. Зростае роль і значення цифрових платформ i нових цифрових інфрраструктур у створенні ціннісної пропозиції. Характеристики цифрових бізнес-моделей, крім орієнтації на клієнта, такі: засновані переважно на електронних платформах; спілкування між гравцями ринку в онлайн-середовищі 3 використанням відповідних інструментів; поєднання системи продажів, зв'язку та доходів; характер мережі [5].

Початок карантину поставив перед бізнессектором багато нових викликів. Виникли питання щодо майбутнього, яке стало абсолютно незрозумілим і закритим, зокрема, для малого та середнього бізнесу. Великі та середні компанії, звичайно, мають кращий запас міцності, тому більшість компаній, які зазнали фінансових втрат, тобто $36 \%$ зазнали втрати до $20 \%$ доходу. Тоді як збитки малого бізнесу значно більші - третина ФОП, а саме $33 \%$ відзначають 50-75\% втрати доходів, а також значне збільшення дебіторської заборгованості [6].

Загалом, карантин в Україні дуже негативно вдарив у бізнес. Лише у ресторанній сфрері на початок карантину без роботи залишилося 160 тисяч осіб. У березні, наприклад, порівняно з лютим, обороти кафе та ресторанів зменшилися вп'ятеро.

За дослідженням Ukrainian Marketing Group станом на березень 2020 року 29\% українських компаній призупинили свою діяльність, а 6\% повністю закрили свій бізнес. Дослідницька група Advanter Group та Український Інститут Майбутнього провели свій аналіз, який показав таке: за збереження поточної тенденції вже за 3-4 тижні закриеться 10\% українських компаній. Через 1-2 місяці - ще 26\%. Однак варто пам'ятати, що у світі бізнесу виживають не сильніші, а гнучкіші та легкі у пристосовуванні. Головне - вчасно відстежити тенденщії, проаналізувати попит на ринку, що з'явився, і активно працювати над 

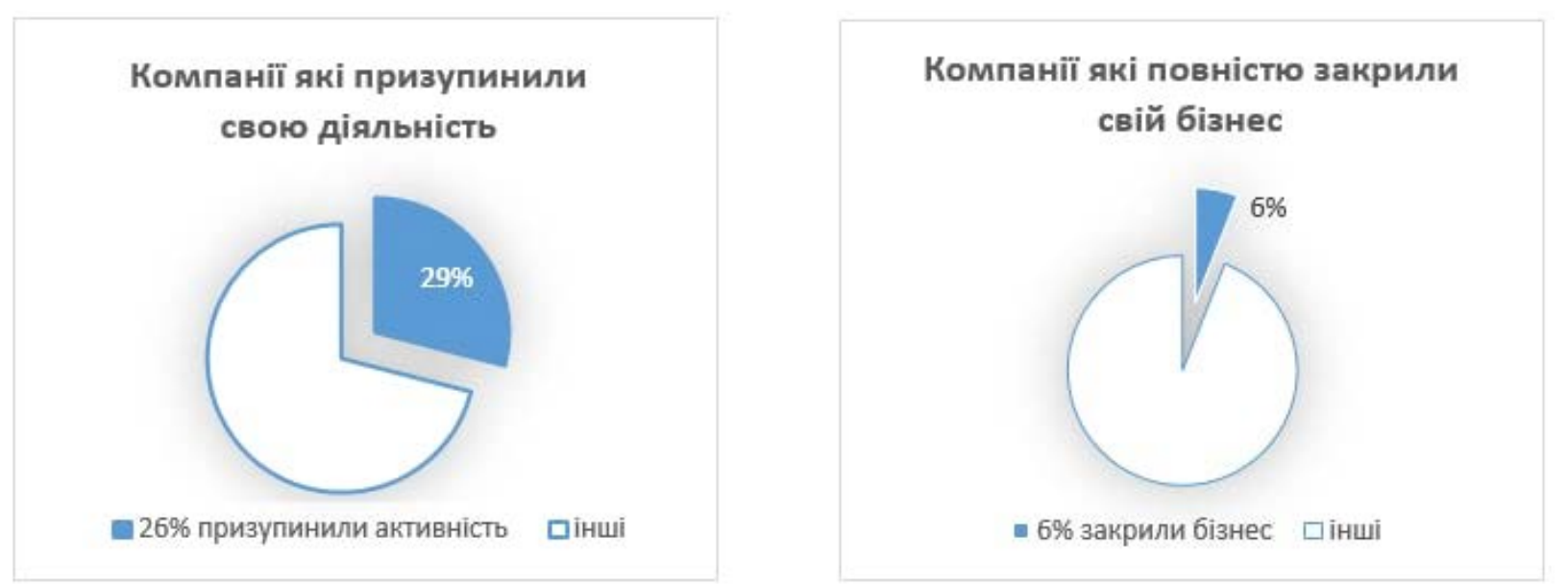

Діаграма 1. Стан українських компаній станом на початок карантину березень 2020 року

Джерело: створено авторами на основі [7]

його задоволенням. Як повідомляє Мінфін, тотальний карантин спровокував сплеск попиту на послуги доставки та інші послуги, які дозволяють споживачеві забезпечувати свої потреби, залишаючись вдома [7].

Масовий перехід до дистанційної роботи, особливо 3 огляду на поточні умови карантину, змусив багатьох людей звернути увагу на важливість цифровізації бізнесу. Експерти прогнозують виживання та успіх лише тим компаніям, які можуть швидко орієнтуватися та почати впроваджувати нові технології та способи взаємодії. Зрештою, прогнози підтвердилися на практиці. Справи тих, хто до або на початку карантину встиг хоча б частково перевести свої робочі процеси в онлайн, не зазнали таких значних втрат і проблем для компаній, які абсолютно не готові до цифрровізації.

Тепер успіх багатьох компаній залежить від стійкості, гнучкості та креативності генерального директора, а також від командного мислення. Відомий фракт, що центром кожного бізнесу є люди, підтвердився на тисячу відсотків цього кризового періоду. Підтвердженням цьому $є$ той факт, що 82\% компаній зуміли зберегти штат компанії незмінним, а 8\% все ще шукають нових співробітників. Таким чином, підприємства розуміють, що люди є їх найбільшим надбанням.

Все більше компаній бачать свої бізнес-цілі не тільки як отримання прибутку, а й у задоволенні потреб співробітників, партнерів і суспільства. I все більше людей звертають увагу не тільки на продукт чи послугу, які вони обирають, а й на саму компанію - 3 точки зору їі корпоративної культури, соціальної відповідальності та залученості, допомагаючи компанії вирішувати великі проблеми. Думаю, ця тенденщія буде тільки посилюватися. Перед підприемцями також стоїть завдання зрозуміти, що буде важливим для їхніх кліентів у найближчому майбутньому, i реструктурувати свою пропозицію, використовуючи цю інфрормацію.

Таким чином, карантин дав можливість випробувати режим дистанційної роботи, який ще до пандемії став світовим трендом. Наші опитування показують, що як малі, так і великі підприемства готові перейти на дистанційну роботу, оскільки дистанщійна робота має ряд переваг, пов'язаних із співвідношенням ціни та якості. Більше 60\% директорів компаній-членів Асощіації розглядають можливість повної або часткової зміни робочого часу на дистанційну роботу. Світові дослідження показують, що продуктивність співробітників при віддаленій роботі на 20-25\% вище, ніж у стандартній офрісній роботі. Це економить час на дорогу до офрiсу, покращуе баланс між роботою та особистим життям, є можливість наймати людей без прив'язки до конкретного регіону чи міста [8].

Однак деякі галузі та підприємства скористалися пандемією, перейшовши на віддалену роботу та цифрові платформи. Таким чином, торгівля офрісною технікою зросла в 2020 році, оскільки компанії адаптувалися до рішень віддаленої роботи. Цифрові платформи, що пропонують розважальні послуги, такі як Netflix, і комунікаційні послуги, такі як Zoom, також процвітали в цей період. Найбільше від Covid-19 постраждали обслуговуючі компанії, зокрема послуги 3 розміщення та харчування. Далі йдуть непродовольчі виробництва, роздрібна та оптова торгівля, а також подорожі та транспорт. Сектор туризму також сильно постраждав від обмежень на подорожі, накладених практично на всі напрямки, що викликає занепокоєння, оскільки ця галузь забезпечує близько 1/10 робочих місць у світі [9].

Також, особливі вимоги цифрового ведення бізнесу вимагають прискорення.

По-перше, за даних умовах необхідно усунути перешкоди. Це може означати оновлення попередньої технології або усунення непотрібного процесу управління змінами.

По-друге, потрібні інструменти для прискорення: такі моделі, як автоматизація кол-центру або соціальний маркетинг, можуть швидко змінюватися.

По-трете, налаштування ресурсів: перемістить фінансування 3 менш цікавих ініціатив до тих, які зосереджені на нових каналах, цифрових продуктах або послугах, які швидко окупляться.

По-четверте, збільшення вартості активів: проаналізувати активи, наприклад хмарні платформи, які використовуються недостатньо едективно і можуть бути використані для швидкого впровадження інновацій та підвищення стійкості бізнесу [10]. 
Щоб покращити та пришвидшити рівень діджиталізації потрібно:

1. Провести цифрровий аудит свого бізнесу. На цьому етапі важливо описати процеси «як є»: написати основні фрункції компанії; визначити ступінь оцифровування в кожному 3 них (описати, що саме оцифровано, яке обладнання включає елементи на малюнку); скласти перелік програмних продуктів, які на даний момент використовуються в кожному конкретному випадку.

2. Створити цифррову стратегію. Аналіз цієї інформації та прийняття на їі основі рішень дозволить отримати конкурентну перевагу на ринку. Мета оцифровки - прискорити процвітання в мінливому світі.

3. Призначити відповідального за процеси цифрровізації компаній. Його місія - керувати реалізацією стратегії та контролювати інноващї. Щороку на ринку з'являються десятки нових програмних продуктів, які можуть бути досконалішими та едрективнішими, ніж ті, що використовуються у вашому бізнесі. Ваш цифровий менеджер зобов'язаний швидко замінити, обгрунтувати своє рішення та підтвердити його точність точними цифрами, щоб зменшити витрати або збільшити дохід.

Відповідно до використаного визначення, розмір цифрової економіки становить, згідно ощінкам, від 4,5\% до 15,5\% глобального ВВП. Майже $40 \%$ додана вартість, створена в глобальний сектор інорормаційно-комунікаційних технологій (IKT), враховуеться для Сполучених Штатів і Китаю. Працівників у секторі ІКТ у всьому світі збільшилося з 48 мільйонів осіб у 2015 році до 59 млн осіб у 2020 р., проте найбільший відсоток (38\%) працівників працюють у сорері комп'ютерних послуг. Через за той самий період частка сектору IКТ в загальній зайнятості збільшився 3 1,8\% до 2\% [11].

Загалом, впровадження цифррових технологій стирае геоградрічні та фрізичні кордони та відкриває нові економічні перспективи, соціального та культурного розвитку країн, а також зростання регіональної та глобальної конкурентоспроможності.

Висновки і пропозиції. Таким чином, світова пандемія COVID-19, без перебільшення, представляе собою глобальний феномен, який потрібно, оцінювати не як короткотермінове явище, як початок нової ери. При цьму кожне глобальне явище, яке тою чи іншою мірою трансформуе людську цивілізацію, з одного боку, створюе нові можливості (перспективи) для подальшого сталого розвитку, а з другого - може, за певних умов, створювати не лише певні «нейтральні» ризики для особи, суспільства та держави, а й реальні

Шляхи до прискорення цифрової бізнес-моделі

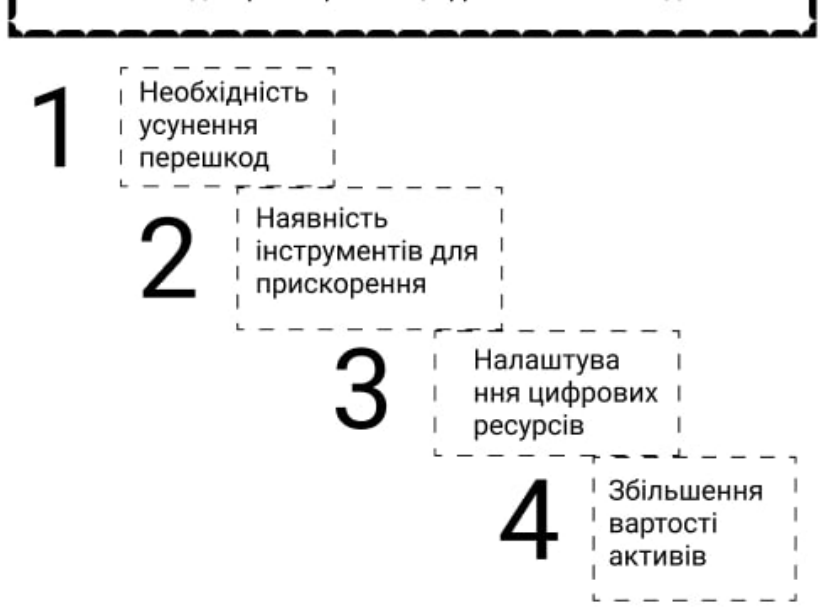

Рис. 1. Шляхи прискорення цифрових бізнес моделей

Джерело: створено авторами на основі [10]

загрози для них. Так, в економічній сфрері відбувається активна трансформація яка вимагає швидкого підлаштування під сучасні умови цифровізації. В свою чергу це вимагае фрінансових вливань, людських ресурсів, та забезпечення їх відповідним технічними засобами. Коронавірус справив безпрецедентний вплив на світ, проте основні складності ще попереду. Компанії мають перебудовуватися вже сьогодні, якщо вони хочуть прийти до норми в майбутньому. Тимчасові покращення, які задовольняють клієнтів зараз, можуть стати постійними покращеннями бізнесмоделей компаній у майбутньому. Для того, щоб покращити та пришвидшити рівень діджиталізації потрібно:

- провести цифровий аудит свого бізнесу;

- створити цифрову стратегію для аналізу інформації та прийняття на їі основі рішень щоб отримати конкурентну перевагу на ринку;

- призначити відповідального за процеси цифровізації компаній для керування реалізацією стратегї та контролювати інноващії компанії.

Підприемщі постійно отримують інформацію про нові задачі функціонування в умовах епідемії. Підприемства, які можуть швидко вивчати ситуащію та засвоювати помилки, що відбувається в інших регіонах та галузях, зможуть краще адаптувати свій бізнес до сьогоднішніх реалій та планувати наступні кроки на майбутне. У мінливому нестійкому світі такий адаптивний підхід повинен застосовуватися і за межами кризового управління.

\section{Список літератури:}

1. Перспективи посткоронавірусних економічних трансформацій для світу та України. За інфорлацією Інституту еконоліки та прогнозування НАН України. 11.11.2021. URL: https://www.nas.gov.ua/UA/Messages/ News/Pages/View.aspx?MessageID=8394

2. Шевченко Л.С. Розвиток бізнес-моделей у цифровій економіці. Цифрові трансформації України 2020: виклики та реалії : зб. наук. пр. НДІ ПЗІР НАПрН України № 1 за матеріалами круглого столу, 18 вересня 2020 р. Харків : НДІ ПЗІР НАПрН України, 2020. С. 183-188. URL: https://openarchive.nure.ua/bitstream/ document/13933/1/ndipzir30.pdf

3. Коронавірусна та посткоронавірусна злочинність: первісні карантинні припущення. Юридичний вісник України. LexInform. 04.06.2020. URL: https://lexinform.com.ua/dumka-eksperta/koronavirusna-ta-postkoronavirusna-zlochynnist-pervisni-karantynni-prypushhennya/ 
4. Лісова Р.М. Вплив діджиталізації на бізнес-моделі: етапи та інструменти цифрової трансформації. Науковий вісник Ужгородського національного університету. 2019. Випуск 24. Частина 2. URL: http://www.visnyk-econom.uzhnu.uz.ua/archive/24_2_2019ua/24.pdf

5. Боденчук Л.Б., Ліганенко І.В. Малий і середній бізнес та цифрові платформи: можливості та загрози. European scientific journal of Economic and Financial innovation. 2021. № 1(7). URL: https://journal.eae.com.ua/ index.php/journal/article/download/120/107

6. Що чекае бізнес у посткоронавірусну епоху. Agronews.ua. 22 червня 2020. URL: https://agronews.ua/news/ shcho-chekaie-biznes-u-postkoronavirusnu-epokhu/

7. Цвіркун Я. Трансформация бизнес-модели в условиях карантина. Ліга.Блоги. 18.04.2020. URL: https://blog.liga.net/user/yrtsvirkun/article/36542

8. Дерев'янко А. Що чекає бізнес у посткоронавірусну епоху. EBA. Європейська Бізнес Асоціація. 22.06.2020. URL: https://eba.com.ua/shho-chekaye-biznes-u-postkoronavirusnu-epohu/

9. Андрощук Г. Ефект пандемії COVID-19: цифрові технології - ключ до розвитку бізнесу. Юридична Газеma online. 01 березня 2021. URL: https://yur-gazeta.com/golovna/efekt-pandemiyi-covid19-cifrovi-tehnologiyi-klyuch-do-rozvitku-biznesu.html

10. Ларіонова Г. Цифровізація бізнесу під час «постпандеміi»: чому необхідна і як прискорити процес вже зараз? Дія Бізнес. URL: https://business.diia.gov.ua/cases/sistematizacia-biznes-procesiv/cifrovizacia-biznesu-pidcas-postpandemii-comu-neobhidna-i-ak-priskoriti-proces-vze-zaraz

11. Пищуліна О. Цифрова економіка: тренди, ризики та соціальні детермінанти. Центр Разулкова. Київ. Жовтень 2020. URL: https://razumkov.org.ua/uploads/article/2020_digitalization.pdf

\section{References:}

1. Perspektyvy postkoronavirusnyx ekonomichnyx transformacij dlya svitu ta Ukrayiny. Za informaciyeyu Instytutu ekonomiky ta prognozuvannya NAN Ukrayiny [Prospects for postcoronavirus economic transformations for the world and Ukraine. According to the Institute of Economics and Forecasting of the National Academy of Sciences of Ukraine] (11.11.2021). Available at: https://www.nas.gov.ua/UA/Messages/News/Pages/View.aspx? MessageID $=8394$

2. Shevchenko L.S. (2020) Rozvytok biznes-modelei u tsyfrovii ekonomitsi. Tsyfrovi transformatsii Ukrainy 2020 : vyklyky ta realii: zb. nauk. pr. NDI PZIR NAPrN Ukrainy № 1 za materialamy kruhloho stolu [Development of business models in the digital economy. Digital Transformations of Ukraine 2020: Challenges and Realities: Coll. Science. etc. Research Institute of NAPRN of Ukraine № 1 on the materials of the round table], September 18. Kharkiv: NDI PZIR NAPrN Ukrainy. Available at: https://openarchive.nure.ua/bitstream/document/13933/1/ ndipzir30.pdf

3. Koronavirusna ta postkoronavirusna zlochynnist: pervisni karantynni prypushchennia [Coronavirus and postcoronavirus crime: initial quarantine assumptions]. Yurydychnyi visnyk Ukrainy. LexInform (04.06.2020). Available at: https://lexinform.com.ua/dumka-eksperta/koronavirusna-ta-postkoronavirusna-zlochynnistpervisni-karantynni-prypushhennya/

4. Lisova R.M. (2019) Vplyv didzhytalizatsii na biznes-modeli: etapy ta instrumenty tsyfrovoi transformatsii [The impact of digitalization on business models: stages and tools of digital transformation]. Naukovyi visnyk Uzhhorodskoho natsionalnoho universytetu, issue 24, part 2. Available at: http://www.visnyk-econom.uzhnu.uz.ua/ archive/24_2_2019ua/24.pdf

5. Bodenchuk L.B., Lihanenko I.V. (2021) Malyi i serednii biznes ta tsyfrovi platformy: mozhlyvosti ta zahrozy [Small and medium business and digital platforms: opportunities and threats]. European scientific journal of Economic and Financial innovation, no. 1(7). Available at: https://journal.eae.com.ua/index.php/journal/article/ download/120/107

6. Shcho chekaie biznes u postkoronavirusnu epokhu [What awaits business in the postcoronavirus era]. Agronews.ua. (June 22, 2020). Available at: https://agronews.ua/news/shcho-chekaie-biznes-u-postkoronavirusnu-epokhu/

7. Tsvirkun Ya. Transformatsyia byznes-modely v uslovyiakh karantyna [Transformation of the business model in quarantine]. League. Blogs (18.04.2020). Available at: https://blog.liga.net/user/yrtsvirkun/article/36542

8. Derevianko A. Shcho chekaie biznes u postkoronavirusnu epokhu. EBA. Yevropeiska Biznes Asotsiatsiia [What awaits business in the postcoronavirus era] (22.06.2020). Available at: https://eba.com.ua/shho-chekaye-biznes-upostkoronavirusnu-epohu/

9. Androshchuk H. Efekt pandemii COVID-19: tsyfrovi tekhnolohii - kliuch do rozvytku biznesu [The effect of the Covid-19 pandemic: digital technologies - the key to business development]. Yurydychna Hazeta online (March 1, 2021). Available at: https://yur-gazeta.com/golovna/efekt-pandemiyi-covid19-cifrovi-tehnologiyi-klyuch-do-rozvitku-biznesu.html

10. Larionova H. Tsyfrovizatsiia biznesu pid chas «postpandemii»: chomu neobkhidna i yak pryskoryty protses vzhe zaraz? [Digitization of business during the "postpandemic": why is it necessary and how to speed up the process now?]. Diia Biznes. Available at: https://business.diia.gov.ua/cases/sistematizacia-biznes-procesiv/cifrovizaciabiznesu-pid-cas-postpandemii-comu-neobhidna-i-ak-priskoriti-proces-vze-zaraz

11. Pyshchulina O. Tsyfrova ekonomika: trendy, ryzyky ta sotsialni determinanty [Digital economy: trends, risks and social determinants]. Tsentr Razumkova. Kyiv. October 2020. Available at: https://razumkov.org.ua/uploads/ article/2020_digitalization.pdf 